\title{
Management of Low-Risk Patients With Thyroid Carcinoma and Detectable Thyroglobulin on T4 After Thyroidectomy and Ablation With lodine-131
}

\begin{abstract}
Objective: To evaluate the positive predictive value of detectable Tg during T4 therapy ( $\mathrm{Tg}$ on $\mathrm{T} 4$ ) in patients with thyroid cancer after total thyroidectomy and remnant ablation, discussing the work-up in this situation and the empirical indication of ${ }^{131}$ I. Patients and methods: Initially, 234 low-risk patients [tumor $\leq$ $5 \mathrm{~cm}$, completely resected, no extensive extrathyroid invasion (pT4)] submitted to total thyroidectomy and ablation with ${ }^{131}$ I $(3.7-5.5 \mathrm{GBq})$ who presented no ectopic uptake on RxWBS were studied. Of these, 23 patients with detectable Tg on T4 (> $1 \mathrm{ng} / \mathrm{ml}$ ) during the first year after initial therapy were selected. Results: Metastases were detected by neck US in 7 patients, by chest CT in 2 and by US and CT in 3. Four of five patients with lung metastases upon CT had a positive RxWBS. Eleven patients with negative US and CT received a new ${ }^{131}$ I dose (without DxWBS), and RxWBS showed ectopic uptake in 3 patients. Among the patients with negative RxWBS, 7 remained free of apparent disease and $\mathrm{Tg}$ was declining (5 with undetectable $\mathrm{Tg}$ on $\mathrm{T} 4$ at the end of the study). One patient presented an increase in $\mathrm{Tg}$ and FDG-PET was positive for lymph node and bone metastases. Conclusions: All patients with $\mathrm{Tg}$ on $\mathrm{T} 4>5 \mathrm{ng} / \mathrm{ml}$ presented apparent disease. In these cases, even when US and CT are negative, the administration of a therapeutic dose of 131 I (without DxWBS) and FDG-PET are recommended. Among patients with detectable $\mathrm{Tg}$ on $\mathrm{T} 4 \leq 5 \mathrm{ng} / \mathrm{ml}$ and negative US and CT, only $12 \%$ presented ectopic uptake on RxWBS. These cases could be followed up by monitoring $\mathrm{Tg}$ on T4, and RxWBS and FDG-PET should only be performed if this marker does not decrease after 1-2 years. (Arq Bras Endocrinol Metab 2007;51/1:99-103)
\end{abstract}

Keywords: Detectable Tg on T4; Radioiodine; Thyroid cancer

\section{RESUMO}

Manuseio de Pacientes com Carcinoma de Tireóide de Baixo Risco e com Tiroglobulina Detectável Durante T4 após Tireoidectomia e Ablação com 131 lodo.

Objetivo: Avaliar o valor preditivo positivo da Tg detectável durante terapia com T4 (Tg sob T4) em pacientes com câncer de tireóide após tireoidectomia total e ablação dos remanescentes, discutindo o manuseio dessa situação e a indicação empírica de ${ }^{131} \mathrm{I}$. Pacientes e métodos: Inicialmente, foram estudados 234 pacientes de baixo risco [tumor $\leq 5 \mathrm{~cm}$, completamente ressecado, sem invasão extratireoideana extensa (pT4)] submetidos à tireoidectomia total e ablação com 131 I (3,7-5,5 GBq) que não apresentaram captação ectópica com RxWBS. Desses, foram selecionados 23 pacientes com Tg detectável com T4 (> 1ng/ml) durante o primeiro ano após a terapia inicial. Resultados: Metástases foram detectadas em 7 pacientes pelo US cervical, em 2 pela TC de tórax e em 3 pela US e TC. Quatro de 5 pacientes com metástases pulmonares à TC tiveram um RxWBS positivo; 11 pacientes com US e TC negativos receberam uma nova dose de ${ }^{131}$ I (sem DxWBS), e a RxWBS mostrou captação ectópica em 3 pacientes. Entre os pacientes com RxWBS negativo, 7 permaneceram livres de doença aparente e a Tg estava em declínio ( $5 \mathrm{com} \mathrm{Tg}$ indetectável sob T4 ao final do estudo). Um paciente apresentou aumento da $\mathrm{Tg}$ e o FDG-PET foi positivo para linfonodos e metástases ósseas. Conclusões: Todos os patients com $\mathrm{Tg}$ sob $\mathrm{T} 4>5 \mathrm{ng} / \mathrm{ml}$ apresentaram doença aparente. Nesses casos, mesmo quando a US e a TC são negativos, é recomendada a administração de dose terapêutica de ${ }^{131}$ I (sem DxWBS) e FDG-PET. Em pacientes com Tg detectável sob T4 $\leq 5 \mathrm{ng} / \mathrm{ml}$, mas US e TC negativos, apenas $12 \%$ apresentaram captação ectópica com a RxWBS. Estes casos podem ser seguidos pelo monitoramento da Tg sob T4, e RxWBS e FDG-PET devem ser feitos apenas se esse marcador não diminuir. (Arq Bras Endocrinol Metab 2007;51/1:99-103)

Descritores: Tg detectável sob T4; Radioiodo; Câncer de tireóide artigo original

\author{
PEDRO W.S. ROSÁRIO \\ MiCHELLE A.R. BORGES \\ GRACIELA B.C. COSTA \\ LEONARDO L. REZENDE \\ EDUARDO L. PADRÃo \\ ÁlvARO L. BARROSO \\ SAULO PURISCH
}

Department of Thyroid,

Endocrinology Service (PWSR, MARB, GBCC, SP), and Nuclear Medicine Service (LLR, ELP, ALB), Santa Casa de Belo Horizonte, MG.

Recebido em 12/04/06

Aceito em 26/05/06 
$\mathrm{T}$ HE IDENTIFICATION OF DETECTABLE levels of thyroglobulin $(\mathrm{Tg})$ during the course of adequate TSH suppression shows a high specificity in the follow-up of patients with thyroid cancer after total thyroidectomy and ablation with ${ }^{131} \mathrm{I}$. In these cases, some authors recommend the administration of a new therapeutic dose of ${ }^{131} \mathrm{I}$, followed by post-treatment whole-body scan (RxWBS) $(1,2)$. However, in the case of low-risk patients the frequency of metastases after total thyroidectomy and ablation with ${ }^{131} \mathrm{I}$ is relatively low in some centers $(3,4)$, a minority of patients without apparent disease may present detectable levels of $\mathrm{Tg}$ during the first year after therapy but become negative for this marker during subsequent evaluations, and many metastases detected by RxWBS can be diagnosed by other imaging methods and treated surgically. Thus, the administration of a new 131I dose (with RxWBS) to low-risk patients with detectable $\mathrm{Tg}$ on $\mathrm{T} 4$ after initial therapy should be discussed, especially when considering that even a 131 I dose of $3.7 \mathrm{GBq}$ (100 $\mathrm{mCi}$ ) can have adverse effects, including a higher risk of tumors (5).

The present study evaluated the positive predictive value of detectable $\mathrm{Tg}$ on $\mathrm{T} 4$ in low-risk patients after thyroidectomy and ablation with ${ }^{131} \mathrm{I}$, discussing the work-up in this situation and the empirical indication of a new radioiodine dose.

\section{PATIENTS AND METHODS}

The initial sample consisted of 234 consecutive patients ( 186 women and 48 men; age range: 13 to 78 years, mean: 47.2 years; 182 with papillary carcinoma and 52 with follicular carcinoma) seen at the Santa Casa de Belo Horizonte, Brazil, and considered to be at low risk for recurrence and mortality (6): tumor $\leq 5 \mathrm{~cm}$ (major diameter), completely resected, no extensive extrathyroid invasion (pT4), non-aggressive histological subtype. Onehundred-and-two patients had lymph node metastases (N1)

Table 1. TNM classification (8) of the patients studied.

\begin{tabular}{|c|c|c|c|}
\hline \multicolumn{4}{|c|}{ TNM stage of the 234 initial patients } \\
\hline & T1 & T2 & T3 \\
\hline No & 42 & 50 & 40 \\
\hline N1 & 24 & 34 & 44 \\
\hline \multicolumn{4}{|c|}{ TNM stage of the 23 selected patients } \\
\hline & T1 & T2 & T3 \\
\hline No & 0 & 1 & 2 \\
\hline N1 & 3 & 6 & 11 \\
\hline
\end{tabular}

and 48 presented minimal extrathyroid invasion (pT3) (table 1). All patients underwent total thyroidectomy and ablation with ${ }^{131} \mathrm{I}(3.7-5.5 \mathrm{GBq}, 100-150 \mathrm{mCi})$, with RxWBS showing no ectopic uptake, and were reassessed during the first year after therapy (6-12 months) by clinical examination and measurement of $\mathrm{Tg}$ during L-T4 therapy $(\mathrm{TSH} \leq 0.3 \mathrm{mIU} / \mathrm{l})(7)$ and antithyroglobulin antibodies (TgAb). Only patients without TgAb were included. Twenty-three patients ( 18 women and 5 men; age range: 16-72 years, mean: 46.5 years; 18 with papillary carcinoma and 5 with follicular carcinoma) with detectable $\mathrm{Tg}$ on $\mathrm{T} 4$ (> $1 \mathrm{ng} / \mathrm{ml}$ ) were selected from the initial group (table 1 ). The investigation protocol of the patients is shown in figure 1. The study was approved by the Research Ethics Committee of our institution.

$\mathrm{Tg}$ was measured with an immunoradiometric assay (ELSA-hTG, CIS bio international, France) with a functional sensitivity of $0.8 \mathrm{ng} / \mathrm{ml}$. TgAb were determined by a chemiluminescent assay (Chemiluminescent ICMA, Nichols Institute Diagnostics, San Juan Capistrano, CA) with a detection limit of $1 \mathrm{IU} / \mathrm{ml}$ and a reference value of up to $2 \mathrm{IU} / \mathrm{ml}$. Based on the functional sensitivity of the assay, a Tg level $>1 \mathrm{ng} / \mathrm{ml}$ was defined as detectable.

RxWBS was performed after the administration of 3.7-5.5 GBq 131I, after T4 withdrawal for 4 weeks and prescription of a low-iodine diet for 2 weeks. Anterior and posterior whole-body images were obtained 7 days after radioiodine administration.

Ultrasound (US) was performed with a linear, multifrequency transducer $(7.5$ to $10 \mathrm{MHz})$. Suspected lymph nodes (9) or cervical masses were submitted to diagnostic biopsy and to surgical excision in selected cases.

Chest and mediastinal computed tomography (CT) was performed on $10-\mathrm{mm}$ sequential sections in the absence of an iodated contrast agent.

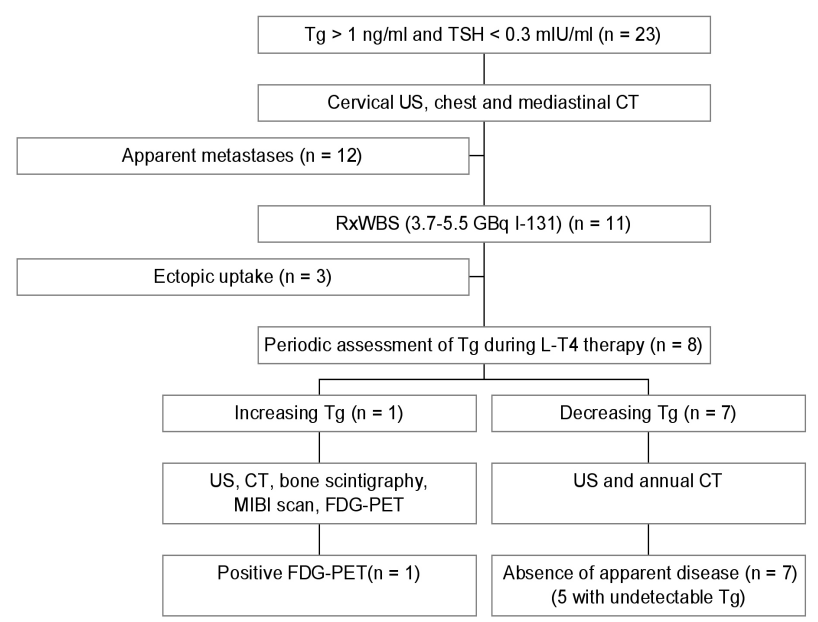

Figure 1. Investigation protocol and number of patients according to the result of the exams. 


\section{RESULTS}

The characteristics of the patients are listed in table 2 and the distribution of the patients according to the results of the investigation is shown in figure 1 .

US revealed suspected lymph node metastases (9) in 10 patients, which were later confirmed by histological analysis. Seven patients were only treated surgically and achieved complete remission (negative stimulated Tg and US) and 3 (with associated lung disease) also received radioiodine, with two of them being in remission.

CT revealed lung micrometastases in 5 patients (3 with positive US). These patients received a new 131 I dose and RxWBS was positive in 4. The patient with negative RxWBS will receive a retinoic acid preparation (10), followed by a new attempt with ${ }^{131} \mathrm{I}$.

Eleven patients with negative US and CT were submitted to empirical therapy with ${ }^{131} \mathrm{I}$ (3.7-5.5 GBq) and RxWBS showed ectopic uptake in 3 (cervical central and mediastinal, only mediastinal, pulmonary). Seven of the eight patients without metastases on US, CT and RxWBS did not develop apparent disease (mean follow-up of 24 months) and probably will not since $\mathrm{Tg}$ is declining (> 50\% decrease) in all of them (11), with Tg during L-T4 therapy being undetectable in 5 . One patient presented an increase in $\mathrm{Tg}$ (from $8 \mathrm{ng} / \mathrm{ml}$ in the first assessment to $19 \mathrm{ng} / \mathrm{ml}$ after 2 years) and FDG-PET revealed lymph node and bone metastases in the mediastinum and femur. Surgical treatment and external radiotherapy were chosen in this case.

No difference was observed in $\mathrm{Tg}$ on $\mathrm{T} 4$ levels (mean) between patients with metastases and those without metastases on US and CT [8.3 versus $5.1 \mathrm{ng} / \mathrm{ml}$ ( $\mathrm{p} \mathrm{ns}$ )], but was higher in the patients with apparent disease in all imaging methods (US, CT, RxWBS and FDG-PET) [9.7 versus 3 $\mathrm{ng} / \mathrm{ml}(\mathrm{p}<0.05)]$.

Of the 13 patients with detectable $\mathrm{Tg} \leq 5 \mathrm{ng} / \mathrm{ml}$, 4 had cervical metastases and one had pulmonary disease diagnosed by US and CT, respectively. Only one of the 8 cases submitted to empirical radioiodine therapy presented ectopic uptake (cervical central and mediastinal) on RxWBS. Among the 10 patients with $\mathrm{Tg}>5 \mathrm{ng} / \mathrm{ml}$, US was positive in 3 , US and CT were positive in 3 , and only CT was positive in 1 . Among the 3 patients submitted to empirical radioiodine therapy, RxWBS revealed pulmonary ectopic uptake in one patient and mediastinal uptake in another, and

Table 2. Characteristics of the patients with detectable $\mathrm{Tg}$ on T4.

\begin{tabular}{|c|c|c|c|c|c|}
\hline Patient & $\begin{array}{l}\text { Age/Gender/ } \\
\text { Histology }\end{array}$ & Tg on T4 (ng/ml) & US & CT & RxWBS (uptake) \\
\hline 1 & 56/F/papillary * & 1.6 & Negative & Negative & Negative \\
\hline 2 & 48/F/follicular * & 2 & Lymph nodes & Negative & - \\
\hline 3 & 29/M/papillary & 2.2 & Negative & Negative & Thyroid bed \\
\hline 4 & $52 / F /$ follicular & 2.5 & Lymph nodes & Negative & - \\
\hline 5 & 50/M/papillary * & 2.5 & Negative & Negative & Negative \\
\hline 6 & 72/F/follicular & 3 & Negative & Negative & Negative \\
\hline 7 & 21/F/papillary * & 3.2 & Negative & Negative & Thyroid bed \\
\hline 8 & 58/F/papillary & 3.5 & Lymph nodes & Negative & - \\
\hline 9 & 35/M/papillary & 3.5 & Negative & Negative & Cervical and mediastinal \\
\hline 10 & 57/F/papillary & 3.8 & Lymph nodes & Negative & - \\
\hline 11 & 46/F/papillary & 4 & Negative & Negative & Negative \\
\hline 12 & 47/F/papillary & 4.2 & Negative & Lung metastases & Pulmonary \\
\hline 13 & 26/M/follicular * & 4.5 & Negative & Negative & Thyroid bed \\
\hline 14 & 32/F/papillary & 5.4 & Lymph nodes & Negative & - \\
\hline 15 & 42/F/papillary & 5.5 & Negative & Negative & Mediastinal \\
\hline 16 & 62/F/papillary & 5.8 & Lymph nodes & Lung metastases & Pulmonary \\
\hline 17 & 70/F/papillary & 6.5 & Lymph nodes & Negative & - \\
\hline 18 & 16/F/papillary $\S$ & 8 & Negative & Negative & Negative \\
\hline 19 & 66/M/follicular & 8.5 & Lymph nodes & Negative & - \\
\hline 20 & 53/F/papillary & 12 & Lymph nodes & Lung metastases & Pulmonary \\
\hline 21 & 32/F/papillary & 18.5 & Negative & Negative & Pulmonary \\
\hline 22 & 62/F/papillary & 20 & Lymph nodes & Lung metastases & Cervical and mediastinal \\
\hline 23 & 36/F/papillary & 26 & Negative & Lung metastases & Negative \\
\hline
\end{tabular}

* Patients without apparent disease and with undetectable Tg on T4 at the end of the study.

$\S$ Subsequent positive FDG-PET for bone and lymph node metastases. 
subsequent FDG-PET showed lymph node and bone metastases in the case with negative RxWBS. These results suggest that the distinction of patients with $\mathrm{Tg}$ levels $\leq 5 \mathrm{ng} / \mathrm{ml}$ during suppressive therapy (12) seems to be relevant (table 3 ).

\section{DISCUSSION}

In the present study, the positive predictive value of detectable $\mathrm{Tg}(>\mathrm{l} \mathrm{ng} / \mathrm{ml})$ during suppressive therapy with L-T4 was 70\% in low-risk patients (6) after total thyroidectomy and ablation with ${ }^{131} \mathrm{I}$ ( $46 \%$ in patients with $\mathrm{Tg} \leq 5 \mathrm{ng} / \mathrm{ml}$ and $100 \%$ if $\mathrm{Tg}>5 \mathrm{ng} / \mathrm{ml}$ ).

No DxWBS was performed in the present series and we directly administered a therapeutic dose of ${ }^{131}$ I (followed by RxWBS) to patients with negative US and CT. DxWBS showed ectopic uptake in only 5 to $33 \%$ of patients with detectable $\mathrm{Tg}$ on $\mathrm{T} 4$ in other series (13-16). We therefore considered DxWBS to be of little value in this situation.

Direct administration of a therapeutic ${ }^{131}$ I dose to these patients would permit the detection of most cases of metastases, with a sensitivity of 75 to $93 \%$ (1315). However, empirical therapy with radioiodine in all patients with detectable $\mathrm{Tg}$ on $\mathrm{T} 4(1,2)$ deserves further discussion. First, because a good part of these patients do not have metastases and would be exposed to high radioiodine activities without any benefit, with this percentage reaching $85 \%$ in very low risk patients (TIN0M0) (16). Second, because most patients with cervical metastases detected by RxWBS could be spared from radioiodine therapy since these metastases can be seen on US (17) and can be managed surgically. The care to avoid unnecessary exposure to radioiodine becomes important in view of the fact that even a dose of $3.7 \mathrm{GBq}^{131} \mathrm{I}$ is associated with adverse effects, including a higher risk of a second neoplasm (5).

We therefore suggest starting the work-up of patients with detectable Tg on T4 with neck US and chest and mediastinal CT. These easily available and noninvasive methods permit to identify most cases of lymph node (cervical and mediastinal) metastases and

Table 3. Positive predictive value considering any detectable $\mathrm{Tg}$ on $\mathrm{T} 4$ ( $\mathrm{n} 23$ ) versus only $\mathrm{Tg} \leq 5 \mathrm{ng} / \mathrm{ml}$ (n 13).

\begin{tabular}{lcc}
\hline Initial investigation & Detectable Tg & Tg $\leq \mathbf{5} \mathbf{~ n g / m l}$ \\
Normal clinical exam & $16 / 23(69.5 \%)$ & $6 / 13(46 \%)$ \\
Negative US & $6 / 13(46 \%)$ & $2 / 9(22 \%)$ \\
Negative US and CT & $4 / 11(36.5 \%)$ & $1 / 8(12.5 \%)$ \\
Negative US, CT and RxWBS & $1 / 8(12.5 \%)$ & $0 / 7(0 \%)$ \\
\hline
\end{tabular}

a good part of lung metastases. The former patients would be referred for surgery (18), with a high chance of remission. For patients with lung micrometastases, a therapeutic radioiodine dose would continue to be indicated but previous knowledge about the presence of radiologically visible metastases might define a specific preparation with retinoic acid (10) or lithium (18). In addition, these methods are able to diagnose most metastases not apparent on RxWBS $(13-15,17)$.

Finally, exclusion of patients with positive US and/or CT reduces the probability of finding apparent disease in the remaining group, especially in patients with $\mathrm{Tg}<5 \mathrm{ng} / \mathrm{ml}$ (only $12 \%$ in the present study). In this group, monitoring Tg during L-T4 therapy would discriminate patients without disease, who present declining $\mathrm{Tg}$ levels, from the minority of patients with metastases who would show an increase in $\mathrm{Tg}$ in subsequent measurements. It is possible that $\mathrm{Tg}$ remains unchanged in some cases with metastases maintained under TSH suppression; however, since these patients are at low risk, have no apparent disease (clinical examination, US and CT) and present no increase in $\mathrm{Tg}$, we do not believe that a possible delay in the diagnosis would compromise the chance of cure in these specific cases. On the other hand, we support the recommendation of a therapeutic dose of ${ }^{131} \mathrm{I}$ and even FDG-PET in patients with $\mathrm{Tg}>5 \mathrm{ng} / \mathrm{ml}$ during L-T4 therapy (12) and negative US and CT. A proposal for investigation is shown in figure 2 .

\section{CONCLUSION}

We concluded that low-risk patients with $\mathrm{Tg}$ on $\mathrm{T} 4 \leq$ $5 \mathrm{ng} / \mathrm{ml}$ and negative US and CT could be followed up by monitoring $\mathrm{Tg}$ on T4 and RxWBS should be performed if this marker does not decrease after 1-2 years. Other studies with more patients and longer follow-up should be done to confirm our results.

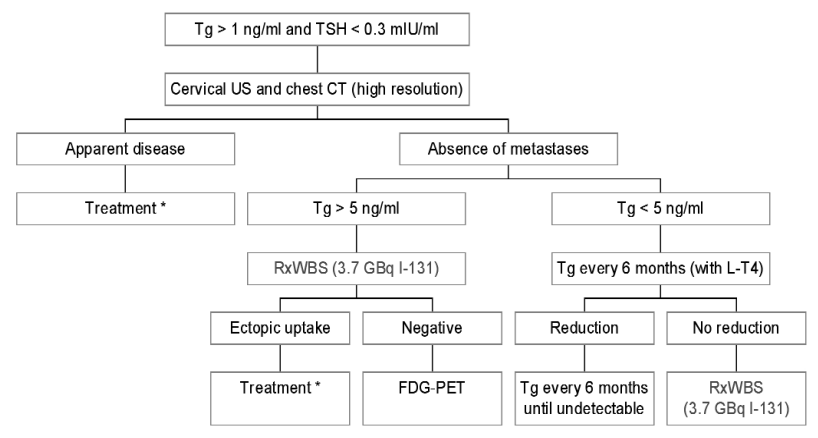

Figure 2. Investigation suggested by the authors for patients with detectable Tg during L-T4 therapy. 


\section{REFERENCES}

1. Pacini F. Follow-up of differentiated thyroid cancer. Eur $\mathbf{J}$ Nucl Med Mol Imaging 2002;29:S492-6.

2. Wartofsky L. Using baseline and recombinant human TSHstimulated $\mathrm{Tg}$ measurements to manage thyroid cancer without diagnostic ${ }^{131}$ I scanning. J Clin Endocrinol Metab 2002;87:1486-9.

3. Cailleux AF, Baudin E, Travagli JP, Ricard M, Schlumberger M. Is diagnostic iodine-131 scanning useful after total thyroid ablation for differentiated thyroid cancer? J Clin Endocrinol Metab 2000;85:175-8.

4. Menendez Torre E, Lopez Carballo MT, Rodriguez Erdozain RM, Forga Llenas L, Goni Iriarte MJ, Barberia Layana JJ. Prognostic value of thyroglobulin serum levels and $131_{\text {I }}$ whole-body scan after initial treatment of low-risk differentiated thyroid cancer. Thyroid 2004;14:301-6.

5. Rubino C, de Vathaire F, Dottorini ME, Hall P, Schvartz C, Couette JE, et al. Second primary malignancies in thyroid cancer patients. Br J Cancer 2003;89:1638-44.

6. Schlumberger M, Berg G, Cohen O, Duntas L, Jamar F, Jarzab $B$, et al. Follow-up of low-risk patients with differentiated thyroid carcinoma: a European perspective. Eur J Endocrinol 2004;150:105-12.

7. Cooper DS, Doherty GM, Haugen BR, Kloos RT, Lee SL, Mandel SJ, et al. The American Thyroid Association Guidelines Taskforce. Guidelines for patients with thyroid nodules and differentiated thyroid cancer. Thyroid 2006;16:109-42.

8. American Joint Committee on Cancer Thyroid 2002. In: Greene FL, Page BL, Fleming ID, Fritz A, Balch CM, Haller BG, et al, eds. AJCC cancer staging handbook. $6^{\text {th }}$ ed. Chapter 8. New York: Springer, 2002. pp. 89-98.

9. Rosário PW, de Faria S, Bicalho L, Alves MF, Borges MA, Purisch S, et al. Ultrasonographic differentiation between metastatic and benign lymph nodes in patients with papillary thyroid carcinoma. J Ultrasound Med 2005;24:1385-9.

10. Gruning T, Tiepolt C, Zophel K, Bredow J, Kropp J, Franke WG. Retinoic acid for redifferentiation of thyroid cancer. Does it hold its promise? Eur J Endocrinol 2003;148:395-402.

11. Baudin E, Do Cao C, Cailleux AF, Leboulleux S, Travagli JP, Schlumberger M. Positive predictive value of serum thyroglobulin levels, measured during the first year of followup after thyroid hormone withdrawal, in thyroid cancer patients. J Clin Endocrinol Metab 2003;88:1107-11.
12. Schlumberger M, Mancusi F, Baudin E, Pacini F. ${ }^{131}$ I therapy for elevated thyroglobulin levels. Thyroid 1997;7:273-6.

13. Pacini F, Molinaro E, Castagna MG, Agate L, Elisei $R$, Ceccarelli $C$, et al. Recombinant human thyrotropinstimulated serum thyroglobulin combined with neck ultrasonography has the highest sensitivity in monitoring differentiated thyroid carcinoma. J Clin Endocrinol Metab 2003;88:3668-73.

14. David A, Blotta A, Rossi R, Zatelli MC, Bondanelli M, Roti E, et al. Clinical value of different responses of serum thyroglobulin to recombinant human thyrotropin in the follow-up of patients with differentiated thyroid carcinoma. Thyroid 2005; 15:267-73.

15. Giovanni V, Arianna LG, Antonio C, Francesco F, Michele K, Giovanni S, et al. The use of recombinant human TSH in the follow-up of differentiated thyroid cancer: experience from a large patient cohort in a single centre. Clin Endocrinol (Oxf) 2002;56:247-52.

16. Torlontano $M$, Attard $M$, Crocetti $U$, Tumino S, Bruno $R$, Costante $\mathrm{G}$, et al. Follow-up of low risk patients with papillary thyroid cancer: role of neck ultrasonography in detecting lymph node metastases. J Clin Endocrinol Metab 2004;89:3402-7.

17. Rosário PW, Guimarães VC, Maia FF, Fagundes TA, Purisch S, Padrão EL, et al. Thyroglobulin before ablation and correlation with posttreatment scanning. Laryngoscope 2005; 115:264-7.

18. Mazzaferri EL. Empirically treating high serum thyroglobulin levels. J Nucl Med 2005;46:1079-88.

Endereço para correspondência:

Pedro Weslley Souza Rosário

Centro de Estudos e Pesquisa

Clinica de Endocrinologia e Metabologia (CEPCEM)

Av. Francisco Sales $1111,5^{\circ}$ andar, Ala D

30150-221 Belo Horizonte, MG

Fax: (31) 3213-0836

E-mail: pedrorosario@globo.com 